\title{
Evidence of Bartonella sp. in questing adult and nymphal Ixodes ricinus ticks from France and co-infection with Borrelia burgdorferi sensu lato and Babesia sp.
}

\author{
Lénaïg HALOS ${ }^{\mathrm{a}}$, Taoufik JAMAL ${ }^{\mathrm{a}}$, Renaud MAILLARD ${ }^{\mathrm{a}, \mathrm{b}}$, \\ Frederic BEUGNET ${ }^{\mathrm{c}}$, Arnaud LE MENACH ${ }^{\mathrm{d}}$, Henri-Jean BoulOUIS ${ }^{\mathrm{a}}$, \\ Muriel VAYSSIER-TAUSSAT ${ }^{\mathrm{a} *}$ \\ a UMR 956 INRA/AFSSA/ENVA/UVPM, Microbiologie, École Nationale Vétérinaire, \\ 7 avenue du Général de Gaulle, 94700 Maisons-Alfort, France \\ b Unité de pathologie du bétail, École Nationale Vétérinaire, 7 avenue du Général de Gaulle, \\ 94700 Maisons-Alfort, France \\ c Merial Europe, 29 avenue T. Garnier, 69007 Lyon, France \\ d INSERM U444, Hôpital Saint-Antoine, 27 rue Chaligny, 75571 Paris Cedex 12, France
}

(Received 25 May 2004; accepted 10 August 2004)

\begin{abstract}
Ticks are known vectors for a wide range of pathogenic microorganisms. Their role in the transmission of some others is so far only suspected. Ticks can transmit multiple pathogens, however, little is known about the co-existence of these pathogens within questing ticks. We looked for the presence of DNA from three micro-organisms, Bartonella sp., Borrelia burgdorferi sensu lato and Babesia sp. which are known or suspected tick-borne pathogens, using a cohort of 92 questing Ixodes ricinus ticks collected from pastures in northern France. DNA was extracted from each individual tick and the presence of the three pathogens was investigated using Polymerase Chain Reaction (PCR) amplification. Nine among 92 samples (9.8\%) demonstrated PCR products using Bartonella specific primers, 3 among 92 (3.3\%) using Borrelia burgdorferi sensu lato specific primers and 19 among 92 (20.6\%) using Babesia specific primers. Seven among 92 samples (7.6\%) were PCR positive for at least two of the pathogens and one sample was positive for all three. Adult ticks $(12 / 18 ; 67 \%)$ showed significantly higher infection rates compared to nymphs $(11 / 74 ; 15 \%)$ for all three pathogens $(P<0.001)$. This study is the demonstration of the simultaneous presence of Bartonella sp., Borrelia burgdorferi sensu lato and Babesia sp. in questing Ixodes ricinus ticks.
\end{abstract}

questing ticks / co-infection / PCR detection

\section{INTRODUCTION}

Tick-borne diseases are of great medical and veterinary importance [41]. Ticks can transmit a large spectrum of pathogens including bacteria, viruses and parasites with a sig- nificant number of these pathogens being agents of emerging infectious diseases.

Bartonella species are emerging arthropod-borne pathogens that cause severe disease in humans and animals $[1,7]$. They have been detected in diverse mammalian

* Corresponding author: mvayssier@ vet-alfort.fr 
hosts such as cats, dogs, rodents, and most recently in ruminants $[7,10,14]$. B. bacilliformis is known to be transmitted by the sand fly [1], B. quintana by the human body louse [28] and $B$. henselae by the cat flea [13]. The vector involved in transmission of Bartonella in ruminants remains unknown, although ticks have been suspected [11]. Bartonella DNA has been detected in engorged Ixodes sp. in Europe [37,39] while the presence of DNA from Bartonella species has been demonstrated in questing Ixodes pacificus ticks in California [11]. Furthermore, there are several reports of co-segregation of Bartonella sp. with known tick-borne pathogens $[4,16,24,39]$, emphasising the putative role of ticks in Bartonella transmission. It has been shown that Bartonella co-segregates in ticks with Borrelia burgdorferi sensu lato [21, 39], the causative agent of Lyme borreliosis and co-segregation of Bartonella with protozoan parasites of the genus Babesia is also suspected [21, 24, 42]. Considering that Bartonella sp. are emerging human pathogens and that ticks can transmit a large spectrum of pathogens to humans, it is, therefore, of high importance to determine the role of ticks in Bartonella transmission.

Lyme borreliosis is the most significant human vector-borne disease in Europe and the United States [2,29] which also occurs in cattle $[8,43]$. Babesia sp., the causative agents of babesiosis are transmitted by ixodid ticks and are capable of infecting a wide variety of vertebrate hosts including humans and cattle [20]. Co-infections of Borrelia burgdorferi sensu lato with Bartonella henselae have been found in patients presenting symptoms of atypical neuroborreliosis [16, 35] while mice have been found to be naturally co-infected with Borrelia burgdorferi, Babesia microti and a novel Bartonella sp. in the USA [21].

Although it is suspected that the Ixodes sp. tick may transmit multiple pathogens [4, $9,27]$, limited work has been carried out on co-infection with multiple pathogens in questing ticks. Testing questing ticks is of greater interest than testing engorged ticks, since the identification of bacterial DNA relates to exposure during the previous blood meal before molting, whereas bacterial DNA identified in engorged ticks may only reflect upon the presence of that organism in the blood of the host.

Clinical surveys show that subjects coinfected by several tick-borne pathogens present more severe symptoms and a longer duration of illness [4]. Co-infection rates among human patients with a confirmed tickborne infection have been reported to be as high as 39\% [4]. However, data on the cosegregation of these tick-borne pathogens in ticks is still lacking.

Our goal was to determine the infection rates of Bartonella sp., Borrelia burgdorferi sensu lato and Babesia sp. in a cohort of nymphal and adult questing Ixodes ricinus ticks tested individually using specific Polymerase Chain Reaction (PCR) primer sets, in order to evaluate the potential vector role of Ixodes ricinus for Bartonella sp. and to establish the simultaneous presence of Borrelia burgdorferi and/or Babesia sp. DNA in ticks infected with Bartonella sp.

\section{MATERIALS AND METHODS}

\subsection{Tick samples}

This study was conducted on 94 questing Ixodes ricinus ticks including 76 nymphs, and 18 adults (9 males and 9 females) collected by flagging two neighbouring pastures during the spring of 2002 in the north of France (Lille area). Each sample was kept individually in absolute ethanol immediately after collection. Prior to extraction, the ticks were taxonomically classified. Each tick was treated individually.

\subsection{DNA extraction}

The ticks were crushed by shaking with a bead beater (mixer mill MM301, Qiagen, Hilden, Germany) and DNA was extracted 
as previously described [19]. The efficiency $(100 \%)$ of DNA extraction was confirmed for 92 Ixodes ricinus samples by PCR amplification of the $16 \mathrm{~S}$ mitochondrial gene using tick-specific primers. Two nymphal samples, for which no amplification products were obtained, were excluded from the study.

\subsection{PCR amplification}

All PCR reactions were performed in a Genamp thermocycler (Applied biosystem, Courtabœuf, France). Each reaction was carried out in $50 \mu \mathrm{L}$ volume containing $0.5 \mu \mathrm{mol} / \mu \mathrm{L}$ of each primer, $2.5 \mathrm{mM}$ of each dNTP, $5 \mu \mathrm{L}$ of $10 \mathrm{X}$ PCR buffer, $1 \mathrm{U}$ of Taq DNA polymerase (Takara biomedical group, Shiga, Japan) and $5 \mu \mathrm{L}$ of the DNA extract. Negative (sterile water) and positive controls were included in each experiment.

The efficiency of tick DNA extraction was evaluated by amplification of a fragment of the tick mitochondrial 16S rRNA gene (ribosomal DNA [rDNA]) using tickspecific primers [6]. The presence of Borrelia burgdorferi sensu lato, Bartonella $\mathrm{sp}$. or Babesia sp. DNA in tick DNA extracts was tested by PCR using specific primers for each of the pathogens [32-34, 39]. The primer sets used in this study and PCR conditions are listed in Table I.

DNA electrophoresis was carried out in $2 \%$ agarose gels containing ethidium bromide, and DNA fragments were visualised under ultraviolet light. Each reaction was performed at least twice.

\subsection{Sequencing and sequence analysis}

All amplified fragments using Bartonella $\mathrm{sp}$. primers were sent for sequencing to GENOMEXPRESS (Meylan, France). The DNA amount was sufficient to allow sequencing for one of the nine Bartonellapositive samples. The sequence, derived from this sample, was compared with known sequences listed in the GenBank nucleotide sequence databases. The BLAST search option of the National Center for Biotech- nology Information (NCBI) (internet site http://www.ncbi.nlm.nih.gov) was used to confirm the origin of the sequence.

\subsection{Statistical analysis}

Chi-square for trends and the Fisher exact test for dichotomous variables were performed on Epi-Info version 3.2 (CDC, Atlanta, GA, USA) and SAS/stat ${ }^{\circledR}$ (version 8.02) softwares. $P<0.05$ was regarded as significant.

\section{RESULTS}

\subsection{Specific detection of Bartonella sp. DNA in questing Ixodes ricinus ticks}

Amongst the 92 samples, 9 (9.8\%), including 6 adults (33\% of the adult ticks) and 3 nymphs ( $4 \%$ of the nymphs) showed an amplified fragment of the expected size for specific amplification of the Bartonella gltA gene (Tab. II). Sequence analysis of the fragment obtained from 1 adult sample (registered in Genbank under the accession number: AY568725) showed 96\% identity with the gltA gene of B. schoenbuschensiis (Genbank accession number: AJ564633). Adult ticks were significantly $(P=0.0015)$ more likely to be infected than nymphs (Tab. II).

\subsection{Specific detection of Borrelia burgdorferi sensu lato and Babesia sp. DNA in ticks}

Visualisation of a $170 \mathrm{bp}$. amplified fragment of B. burgdorferi sensu lato 23S-5S spacer region was obtained for $3(3.3 \%)$ of the 92 samples, of which 2 were adult ticks (11\% of the adult ticks) and one was a nymph (1.3\% of the nymphs) (Tab. II). No statistically significant difference was detected in prevalence of infection between the adults and nymphs.

Amongst the 92 samples, 19 samples $(20.6 \%)$, including 10 adults $(56 \%$ of the adult ticks) and 9 nymphs (12\% of the 
Table I. Oligonucleotide primers used in this study.

\begin{tabular}{|c|c|c|c|c|c|c|c|}
\hline Organism & Template & & Primer sequences 5'-3' & $\begin{array}{l}\text { Product } \\
\text { size bp }\end{array}$ & $\begin{array}{l}\text { Targeted } \\
\text { gene }\end{array}$ & PCR conditions & Reference \\
\hline \multirow[t]{2}{*}{ Tick } & TQ16S+1F & $\mathrm{F}$ & CTGCTCAATGATTTTTTAAATTGTGTGG & 320 & $\begin{array}{l}\text { ADNr 16S } \\
\text { mitochon- } \\
\quad \text { drial }\end{array}$ & $\begin{array}{c}\text { Denaturation: } 94{ }^{\circ} \mathrm{C} 8 \mathrm{~min} \\
\text { Hybridization: } 10 \text { cycles: } \\
92{ }^{\circ} \mathrm{C} 1 \text { min, } 48{ }^{\circ} \mathrm{C} 1 \text { min, } 72{ }^{\circ} \mathrm{C} 1 \mathrm{~min} 30 \mathrm{~s} \\
32 \text { cycles } \\
92{ }^{\circ} \mathrm{C} 1 \text { min, } 54{ }^{\circ} \mathrm{C} 1 \text { min, } 72{ }^{\circ} \mathrm{C} 1 \mathrm{~min} 30 \mathrm{~s} \\
\text { Extension: } 72{ }^{\circ} \mathrm{C} 10 \mathrm{~min}\end{array}$ & {$[6,19]$} \\
\hline & TQ16S-2R & $\mathrm{R}$ & ACGCTGTTATCCCTAGAG & & & & \\
\hline \multirow[t]{2}{*}{$\begin{array}{l}\text { Bartonella } \\
\text { sp. }\end{array}$} & 781 & $\mathrm{~F}$ & GGGGACCAGCTCATGGTGG & 356 & $\begin{array}{c}\text { Citrate } \\
\text { synthase }\end{array}$ & $\begin{array}{l}\text { Denaturation: } 90{ }^{\circ} \mathrm{C} 8 \mathrm{~min} \\
\text { Hybridization: } 35 \text { cycles } \\
93{ }^{\circ} \mathrm{C} 20 \mathrm{~s}, 54{ }^{\circ} \mathrm{C} 30 \mathrm{~s}, 72{ }^{\circ} \mathrm{C} 30 \mathrm{~s} \\
\text { Extension: } 72{ }^{\circ} \mathrm{C} 5 \mathrm{~min}\end{array}$ & {$[32]$} \\
\hline & 1137 & $\mathrm{R}$ & AATGCAAAAAGAACAGTAAACA & & & & \\
\hline \multirow[t]{3}{*}{$\begin{array}{l}\text { Borrelia } \\
\text { burgdorferi } \\
\text { sensu lato }\end{array}$} & $5 \mathrm{SCB}$ & $\mathrm{F}$ & GAGAGTAGGTTATTGCCAGGG & 226 & $\begin{array}{c}23 \mathrm{~S}-5 \mathrm{~S} \\
\text { spacer }\end{array}$ & $\begin{array}{c}\text { Denaturation: } 95{ }^{\circ} \mathrm{C} 8 \text { min } \\
\text { Hybridation: } 30 \text { cycles } \\
94{ }^{\circ} \mathrm{C} 1 \text { min, } 50{ }^{\circ} \mathrm{C} 1 \mathrm{~min}, 72{ }^{\circ} \mathrm{C} 1 \mathrm{~min} \\
\text { Extension: } 72{ }^{\circ} \mathrm{C} 5 \text { min }\end{array}$ & [39] \\
\hline & 23SN2 & $\mathrm{R}$ & ACCATAGACTCTTATTACTTTGACCA & & & & \\
\hline & BORVRigs & $\mathrm{R}$ & AATAATATATATCTTTGTTTAAT & 170 & & & This study \\
\hline \multirow[t]{4}{*}{ Babesia sp. Set 1} & PIRO A & $\mathrm{F}$ & AATACCCAATCCTGACACAGG & 408 & $\begin{array}{l}\text { 18S Small } \\
\text { sub-unit } \\
\text { ribosomal } \\
\text { DNA }\end{array}$ & $\begin{array}{l}\text { Denaturation: } 95^{\circ} \mathrm{C} 8 \text { min } \\
\text { Hybridization: } 30 \text { cycles } \\
94{ }^{\circ} \mathrm{C} 1 \text { min, } 52{ }^{\circ} \mathrm{C} 1 \mathrm{~min}, 72{ }^{\circ} \mathrm{C} 1 \mathrm{~min} \\
\text { Extension: } 72{ }^{\circ} \mathrm{C} 10 \mathrm{~min}\end{array}$ & [33] \\
\hline & PIRO B & $\mathrm{R}$ & TTAAATACGAATGCCCCCAAC & & & & \\
\hline & bab1 & $\mathrm{F}$ & CTTAGTATAAAGCTTTTATACAGC & 230 & $\begin{array}{l}\text { 18S Small } \\
\text { sub-unit } \\
\text { ribosomal } \\
\text { DNA }\end{array}$ & $\begin{array}{c}\text { Denaturation: } 94{ }^{\circ} \mathrm{C} 1 \mathrm{~min} \\
\text { Hybridization: } \\
5 \text { cycles } \\
94{ }^{\circ} \mathrm{C} 1 \mathrm{~min}, 49^{\circ} \mathrm{C} 1 \mathrm{~min}, 72{ }^{\circ} \mathrm{C} 1 \mathrm{~min} \\
30 \text { cycles } \\
94{ }^{\circ} \mathrm{C} 1 \text { min, } 53{ }^{\circ} \mathrm{C} 1 \mathrm{~min}, 72{ }^{\circ} \mathrm{C} 1 \mathrm{~min} \\
\text { Extension: } 72{ }^{\circ} \mathrm{C} 10 \mathrm{~min}\end{array}$ & [34] \\
\hline & bab4 & $\mathrm{R}$ & ATAGGTCAGAAACTTGAATGATACA & & & & \\
\hline
\end{tabular}


Table II. Number of samples from 92 questing Ixodes ricinus ticks showing specific PCR amplification of the gene of the citrate-synthase ( $g l t A$ ) of Bartonella sp., the 23S-5S spacer of Borrelia burgdorferi sensu lato or the gene of the small ribosomal sub-unit (SS-rDNA) of Babesia sp. and number of samples showing simultaneous specific PCR amplification of 2 or 3 of the targeted micro-organisms.

\begin{tabular}{|c|c|c|c|c|c|c|c|c|c|}
\hline \multirow{2}{*}{$\begin{array}{l}\text { Ixodes } \\
\text { ricinus } \\
\text { samples }\end{array}$} & \multicolumn{3}{|c|}{$\begin{array}{c}\text { Detection of pathogen DNA } \\
\text { Number of infected ticks / number of samples (\%) }\end{array}$} & \multicolumn{5}{|c|}{$\begin{array}{l}\text { Co-detection of pathogen DNA } \\
\text { Number of infected ticks / number of samples (\%) }\end{array}$} & \multirow{2}{*}{$\begin{array}{c}\text { Number of coinfected } \\
\text { ticks / number of } \\
\text { infected ticks }(\%)\end{array}$} \\
\hline & $\begin{array}{l}\text { Bartonella } \\
\quad \text { sp. }\end{array}$ & Babesia sp. & $\begin{array}{l}\text { Borrelia } \\
\text { burgdorferi s.l. }\end{array}$ & $\begin{array}{l}\text { Bartonella / } \\
\text { Borrelia }\end{array}$ & $\begin{array}{l}\text { Bartonella / } \\
\text { Babesia }\end{array}$ & $\begin{array}{l}\text { Borrelia/ } \\
\text { Babesia }\end{array}$ & $\begin{array}{c}\text { Bartonella / } \\
\text { Borrelia / } \\
\text { Babesia }\end{array}$ & $\begin{array}{l}\text { Total number of } \\
\text { co-infected ticks }\end{array}$ & \\
\hline Females & 3/9 (33) & 6/9 (67) & $1 / 9(11)$ & $0 / 9(0)$ & $3 / 9(33)$ & $1 / 9(11)$ & $0 / 9(0)$ & $4 / 9(44)$ & $4 / 6(67)$ \\
\hline Males & $3 / 9$ (33) & 4/9 (44) & $1 / 9(11)$ & $0 / 9(0)$ & $0 / 9(0)$ & $0 / 9(0)$ & $1 / 9(11)$ & $1 / 9(11)$ & $1 / 6(17)$ \\
\hline Nymphs & 3/74 (4) & $9 / 74$ (12) & $1 / 74(1.3)$ & $1 / 74(1.3)$ & $1 / 74(1.3)$ & 0/74 (0) & 0/74 (0) & $2 / 74(2.7)$ & 2/11 (18) \\
\hline Total & 9/92 (9.8) & $19 / 92(20.6)$ & $3 / 92(3.3)$ & $1 / 92(1)$ & $4 / 92(4)$ & $1 / 92(1)$ & 1/92 (1) & 7/92 (7.6) & $7 / 23(31)$ \\
\hline
\end{tabular}


nymphs), showed a $400 \mathrm{bp}$ amplified fragment of Babesia sp. SS-rDNA gene using a first set of primers. The presence of babesial DNA in the sample was further confirmed by a second PCR amplification of a $230 \mathrm{bp}$ fragment of the SS-rDNA gene using a second set of Babesia sp. primers (set 2, Tab. I). All 19 positive samples showed an amplified fragment of the expected size (Tab. II). Adult ticks were almost ten times more likely to be PCR positive for Babesial DNA than nymphs (Odds ratio: $9.03 ; 95 \%$ confidence intervals: $2.42-33.69 ; P<0.001)$.

Overall, $7(7.6 \%)$ of the ticks were found to be co-infected with at least two pathogens, accounting for $30 \%$ of the 23 infected ticks (Tab. II). Among the three Borrelia burgdorferi sensu lato positive samples, all were co-infected. The positive nymph was also found to be PCR positive for Bartonella sp., one of the two positive adult ticks was also found to be PCR-positive for Babesia sp. and the second one was also positive for the two other agents tested (Tab. II). Among the 19 Babesia sp. positive samples, three adults and one nymph were also found to be PCR positive for Bartonella while one adult was PCR positive for Borrelia burgdorferi sensu lato (Tab. II). Among the adult ticks, the prevalence of co-infection was higher in female ticks $(4 / 9 ; 44 \%)$ than in male ticks $(1 / 9 ; 11 \%)$, but that difference was not statistically significant.

\section{DISCUSSION}

The present study provided evidence for the common co-existence of various tickborne pathogens in Ixodid ticks and for the first time, the simultaneous presence of Bartonella sp., Borrelia burgdorferi sensu lato and Babesia sp. DNA in the same tick.

Our study confirmed the presence of Bartonella sp. DNA in European questing ticks since $9.8 \%$ of the samples were found to be positive by PCR for Bartonella sp. supporting the hypothesis that Bartonella bacteria can be carried by ticks. The partial sequence of the citrate-synthase ( $g l t A)$ gene obtained from one sample was related to Bartonella schoenbuschensis (96\% similarity) which infects the roe-deer (Capreolus capreolus) in Europe [14]. The presence of Bartonella in ruminant blood at very high infection levels has been previously reported [10]. Since the DNA of ruminant-related Bartonella species has already been detected in Ixodid ticks, they have been suspected to be a potential source of infection for ruminants $[11,39]$. Considering that Ixodes ticks feed once per stage, the presence of Bartonella in questing ticks at different developmental stages would suggest the possibility of transstadial transmission of these bacteria, potentially related to transmission to mammalian hosts.

The analysis of the same tick cohort for co-infection with other pathogens revealed that $3.3 \%$ of the ticks were PCR positive for Borrelia burgdorferi sensu lato and $20.6 \%$ for Babesia sp. The prevalence of 3.3\% of B. burgdorferi sensu lato PCR-positive ticks is relatively low compared with other studies probably due to the ecological habitat from where the samples were collected. Reported prevalences of $B$. burgdorferi sensu lato in ticks vary from $1.3 \%$ in Switzerland [5] to 55\% in areas of Finland [23] with an average between 10 and 20\% [9, 22, $29,36]$. Here, we investigated a tick population living on pastures. Since reservoirs for Lyme borreliosis are often forest living rodents, the prevalence of Lyme spirochetes is naturally higher in wood or fields near wood areas than in pastures $[18,38]$. However, the presence of Borrelia burgdorferi sensu lato DNA in ticks collected on pastures strongly suggests that the risk for borreliosis is not limited to decidual forest areas.

Twenty-one percent of questing Ixodes ricinus ticks were PCR positive for Babesia sp., which correlates with infection rates described in other studies: between $6.2 \%$ and $62 \%$ of babesial infection in questing $[3,15]$, or engorged ticks [17]. Although the particular species of Babesia was not determined by sequencing, we confirmed that 
the amplification was specific to Babesia sp. by using two different sets of primers which were described to be specific to the Babesia genus [33, 34].

Interestingly, adult ticks showed significantly higher infection rates compared to nymphs for all three pathogens. Previous studies have already shown different ranges of prevalence between adults and nymphs, for Borrelia burgdorferi [9, 22], for Babesia sp. [26] and Bartonella sp. [12]. One hypothesis explaining this difference is the number of potentially infected meals which is higher for adults than for nymphs (two blood meals for adults versus one for nymphs). This could either be related to the existence of stage-specific factors, favouring the acquisition of the pathogen by the tick at a special stage as previously shown for other vector arthropods such as tsetse flies [31]. It is noteworthy that despite the lack of a statistically significant difference in infection rates between males and females for any of the targeted pathogens, females were coinfected more often (44\%) than males (11\%).

Up to $7.6 \%$ of the ticks were co-infected with at least two pathogens and $30 \%$ of the infected ticks were co-infected (Tab. II). Borrelia burgdorferi and Bartonella sp. have already been simultaneously detected in ticks collected on wild ruminants [39] whereas the coexistence of DNA of Borrelia burgdorferi sensu lato and Babesia microti in Ixodes ricinus ticks showed rates ranging from $2 \%$ to $19 \%[4,40]$. Our results emphasise the fact that the co-existence of pathogens is not a rare event in ticks. This co-existence appears to be linked with cosegregations or co-infections in mammals including humans $[4,16,21,27,30,42]$. An increasing number of studies suggest that symptoms attributed to one tick-borne disease are not due to a single pathogen [25]. For example, patients with ongoing symptoms attributed to chronic Lyme disease have been shown to be co-infected with Bartonella sp. [16, 35] or Babesia sp. and Ehrlichia sp. [25]. Immunoserologic evidence of co-infection with $B$. burgdorferi sensu lato and Babesia sp. among individuals in tick-endemic areas is also well documented [27, 30].

This study confirms the fact that the coexistence of Bartonella sp. and/or Babesia sp. and/or Borrelia burgdorferi sensu lato, occurs in ticks. Factors affecting tick co-infections and the risk to humans posed by such coinfections in terms of therapy will need further studies.

\section{ACKNOWLEDGMENTS}

We are grateful to Prof. Bruno Chomel and Dr Maria Mavris for critical review, and stimulating discussion. We thank Cédric Trottet and Benjamin Girard for their excellent technical assistance, Stéphanie Akardjoudje and Arnaud Cossart for harvesting ticks, Dr Benoit Jauhlac and Pascal Boireau for having kindly provided Borrelia and Babesia DNA. This work was supported by the Institut National de la Recherche Agronomique and Mérial.

\section{REFERENCES}

[1] Alexander B., A review of bartonellosis in Ecuador and Colombia, Am. J. Trop. Med. Hyg. 52 (1995) 354-359.

[2] Barthold S.W., Globalisation of Lyme borreliosis, Lancet 348 (1996) 1603.

[3] Battsetseg B., Xuan X., Ikadai H., Bautista J.L., Byambaa B., Boldbaatar D., Battur B., Battsetseg G., Batsukh Z., Igarashi I., Nagasawa H., Mikami T., Fujisaki K., Detection of Babesia caballi and Babesia equi in Dermacentor nuttalli adult ticks, Int. J. Parasitol. 31 (2001) 384-386.

[4] Belongia E., Epidemiology and impact of coinfections acquired from Ixodes ticks, Vector Borne Zoonotic Dis. 2 (2002) 265-273.

[5] Bernasconi M.V., Valsangiacomo C., Balmelli T., Peter O., Piffaretti J.C., Tick zoonoses in the southern part of Switzerland (Canton Ticino): occurrence of Borrelia burgdorferi sensu lato and Rickettsia sp., Eur. J. Epidemiol. 13 (1997) 209-215.

[6] Black W.C., Piesman J., Phylogeny of hard and soft-tick taxa (Acari: Ixodida) based on mitochondrial 16S rDNA sequences, Proc. Natl. Acad. Sci. USA 91 (1994) 10034-10038. 
[7] Breitschwerdt E.B., Kordick D.L., Bartonella infection in animals: carriership, reservoir potential, pathogenicity, and zoonotic potential for human infection, Clin. Microbiol. Rev. 13 (2000) 428-438.

[8] Burgess E.C., Gendron-Fitzpatrick A., Wright W.O., Arthritis and systemic disease caused by Borrelia burgdorferi infection in a cow, $\mathrm{J}$. Am. Vet. Med. Assoc. 191 (1987) 1468-1470.

[9] Cao W.C., Zhao Q.M., Zhang P.H., Yang H., Wu X.M., Wen B.H., Zhang X.T., Habbema J.D., Prevalence of Anaplasma phagocytophila and Borrelia burgdorferi in Ixodes persulcatus ticks from northeastern China, Am. J. Trop. Med. Hyg. 68 (2003) 547-550.

[10] Chang C.C., Chomel B.B., Kasten R.W., Heller R.M., Ueno H., Yamamoto K., Bleich V.C., Pierce B.M., Gonzales B.J., Swift P.K., Boyce W.M., Jang S.S., Boulouis H.J., Piemont Y., Bartonella sp. isolated from wild and domestic ruminants in North America, Emerg. Infect. Dis. 6 (2000) 306-311.

[11] Chang C.C., Chomel B.B., Kasten R.W., Romano V., Tietze N., Molecular evidence of Bartonella sp. in questing adult Ixodes pacificus ticks in California, J. Clin. Microbiol. 39 (2001) 1221-1226.

[12] Chang C.C., Hayashidani H., Pusterla N., Kasten R.W., Madigan J.E., Chomel B.B., Investigation of Bartonella infection in ixodid ticks from California, Comp. Immunol. Microbiol. Infect. Dis. 25 (2002) 229-236.

[13] Chomel B.B., Kasten R.W., Floyd-Hawkins K., Chi B., Yamamoto K., Roberts-Wilson J., Gurfield A.N., Abbott R.C., Pedersen N.C., Koehler J.E., Experimental transmission of Bartonella henselae by the cat flea, J. Clin. Microbiol. 34 (1996) 1952-1956.

[14] Dehio C., Lanz C., Pohl R., Behrens P., Bermond D., Piemont Y., Pelz K., Sander A., Bartonella schoenbuchii sp. nov., isolated from the blood of wild roe deer, Int. J. Syst. Evol. Microbiol. 51 (2001) 1557-1565.

[15] Duh D., Petrovec M., Avsic-Zupanc T., Diversity of Babesia infecting European sheep ticks (Ixodes ricinus), J. Clin. Microbiol. 39 (2001) 3395-3397.

[16] Eskow E., Rao R.V., Mordechai E., Concurrent infection of the central nervous system by Borrelia burgdorferi and Bartonella henselae: evidence for a novel tick-borne disease complex, Arch. Neurol. 58 (2001) 1357-1363.

[17] Foppa I.M., Krause P.J., Spielman A., Goethert H., Gern L., Brand B., Telford S.R., Entomologic and serologic evidence of zoonotic trans- mission of Babesia microti, eastern Switzerland, Emerg. Infect. Dis. 8 (2002) 722-726.

[18] Gray J.S., Kahl O., Janetzki C., Stein J., Guy E., The spatial distribution of Borrelia burgdorferi-infected Ixodes ricinus in the Connemara region of County Galway, Ireland, Exp. Appl. Acarol. 19 (1995) 163-172.

[19] Halos L., Jamal T., Vial L., Maillard R., Suau A., Le Menach A., Boulouis H.J., VayssierTaussat M., Determination of an efficient and reliable method for DNA extraction from ticks, Vet. Res. 35 (2004) 709-713.

[20] Homer M.J., Aguilar-Delfin I., Telford S.R. 3rd, Krause P.J., Persing D.H., Babesiosis, Clin. Microbiol. Rev. 13 (2000) 451-469.

[21] Hofmeister E.K., Kolbert C.P., Abdulkarim A.S., Magera J.M., Hopkins M.K., Uhl J.R., Ambyaye A., Telford S.R., Cockerill F.R., Persing D.H., Cosegregation of a novel Bartonella species with Borrelia burgdorferi and Babesia microti in Peromyscus leucopus, J. Infect. Dis. 177 (1998) 409-416.

[22] Hubalek Z., Halouzka J., Juricova Z., Longitudinal surveillance of the tick Ixodes ricinus for Borreliae, Med. Vet. Entomol. 17 (2003) 46-51.

[23] Junttila J., Peltomaa M., Soini H., Marjamaki M., Viljanen M.K., Prevalence of Borrelia burgdorferi in Ixodes ricinus ticks in urban recreational areas of Helsinki, J. Clin. Microbiol. 37 (1999) 1361-1365.

[24] Kordick S.K., Breitschwerdt E.B., Hegarty B.C., Southwick K.L., Colitz C.M., Hancock S.I., Bradley J.M., Rumbough R., Mcpherson J.T., MacCormack J.N., Coinfection with multiple tick-borne pathogens in a Walker Hound kennel in North Carolina, J. Clin. Microbiol. 37 (1999) 2631-2638.

[25] Krause P.J., McKay K., Thompson C.A., Sikand V.K., Lentz R., Lepore T., Closter L., Christianson D., Telford S.R., Persing D., Radolf J.D., Spielman A., Disease-specific diagnostis of coinfecting tick-borne zoonoses: babesiosis, human granulocytic ehrlichiosis, and Lyme disease, Clin. Infect. Dis. 34 (2002) 1184-1191.

[26] Kuzna-Grygiel W., Bukowska K., Cichocka A., Kosik-Bogacka D., Skotarczak B., The prevalence of piroplasms in a population of Ixodes ricinus (Acari: Ixodidae) from northwestern Poland, Ann. Agric. Environ. Med. 9 (2002) 175-178

[27] Magnarelli L.A., Dumier J.S., Anderson J.F., Coexistence of antibodies to tick-borne pathogens of babesiosis, ehrlichiosis and Lyme 
borreliosis in human sera, J. Clin. Microbiol. 33 (1995) 3054-3057.

[28] Maurin M., Raoult D., Bartonella (Rochalimaea) quintana infections, Clin. Microbiol. Rev. 9 (1996) 273-292.

[29] Michalik J., Hofman T., Buczek A., Skoracki M., Sikora B., Borrelia burgdorferi s.l. in Ixodes ricinus (Acari: Ixodidae) ticks collected from vegetation and small rodents in recreational areas of the city of Poznan, J. Med. Entomol. 40 (2003) 690-697.

[30] Mitchell P.D., Reed K.D., Hofkes J.M., Immunoserologic evidence of co-infection with Borrelia burdorferi, Babesia microti and human granulocytic Ehrlichia species in residents of Winsconsin and Minnesota, J. Clin. Microbiol. 34 (1996) 724-727.

[31] Nantulya V.M., Doyle J.J., Jenni L., Studies on Trypanosoma (nannomonas) congolense II. Observations on the cyclical transmission of three field isolates by Glossina morsitans morsitans, Acta Trop. 35 (1978) 339-344.

[32] Norman A.F., Regnery R., Jameson P., Greene C., Krause D.C., Differentiation of Bartonellalike isolates at the species level by PCRrestriction fragment length polymorphism in the citrate synthase gene, J. Clin. Microbiol. 33 (1995) 1797-1803.

[33] Olmeda A.S., Armstrong P.M., Rosenthal B.M., Valladares B., Del Castillo A., De Armas F., Miguelez M., Gonzalez A., Rodriguez J.A., Spielman A., Telford S.R., A subtropical case of human babesiosis, Acta Trop. 67 (1997) 229-234.

[34] Persing D.H., Mathiesen D., Marshall W.F., Telford S.R., Spielman A., Thomford J.W., Conrad P.A., Detection of Babesia microti by polymerase chain reaction, J. Clin. Microbiol. 30 (1992) 2097-2103.

[35] Podsiadly E., Chmielewski T., TylewskaWierzbanowska S., Bartonella henselae and Borrelia burgdorferi infections of the central nervous system, Ann. NY Acad. Sci. 990 (2003) 404-406.
[36] Quessada T., Martial-Convert F., Arnaud S., Leudet De La Vallee H., Gilot B., Pichot J., Prevalence of Borrelia burgdorferi species and identification of Borrelia valaisiana in questing Ixodes ricinus in the Lyon region of France as determined by polymerase chain reaction-restriction fragment length polymorphism, Eur. J. Clin. Microbiol. Infect. Dis. 22 (2003) 165-173.

[37] Sanogo Y.O., Zeaiter Z., Caruso G., Merola F., Shpynov S., Brouqui P., Raoult D., Bartonella henselae in Ixodes ricinus ticks (Acari: Ixodida) removed from humans, Belluno province, Italy, Emerg. Infect. Dis. 9 (2003) 329-332.

[38] Shapiro E.D., Gerber M.A., Lyme disease, Clin. Infect. Dis. 31 (2000) 533-542.

[39] Schouls L., Van de Pol I., Rijpkema S.G.T., Schot C.S., Detection and identification of Ehrlichia, Borrelia burgdorferi sensu lato, and Bartonella Species in Dutch Ixodes ricinus Ticks, J. Clin. Microbiol. 37 (1999) 2215 2222.

[40] Skotarczak B., Wodecka B., Cichocka A., Coexistence DNA of Borrelia burgdorferi sensu lato and Babesia microti in Ixodes ricinus ticks from north-western Poland, Ann. Agric. Environ. Med. 9 (2002) 25-28.

[41] Sparagano O.A., Allsopp M.T., Mank R.A., Rijpkema S.G., Figueroa J.V., Jongejan F., Molecular detection of pathogen DNA in ticks (Acari: Ixodidae): a review, Exp. Appl. Acarol. 23 (1999) 929-960.

[42] Suksawat J., Xuejie Y., Hancock S.I., Hegarty B.C., Nilkumhang P., Breitschwerdt E.B., Serologic and molecular evidence of coinfection with multiple vector-borne pathogens in dogs from Thailand, J. Vet. Intern. Med. 15 (2001) 453-462.

[43] Tuomi J., Rantamaki L.K., Tanskanen R., Experimental infection of cattle with several Borrelia burgdorferi sensu lato strains; immunological heterogeneity of strains as revealed in serological tests, Vet. Microbiol. 60 (1998) $27-43$. 